January 2011

\title{
Is Immigration Policy Labor Policy? Immigration Enforcement, Undocumented Workers, and the State
}

Ruth Gomberg-Munoz

Loyola University Chicago, rgombergmunoz@gmail.com

Laura Nussbaum-Barberena

Follow this and additional works at: https://ecommons.luc.edu/social_justice

Part of the Social and Cultural Anthropology Commons

\section{Recommended Citation}

Gomberg-Munoz, Ruth and Nussbaum-Barberena, Laura, "Is Immigration Policy Labor Policy? Immigration Enforcement, Undocumented Workers, and the State" (2011). Social Justice. 1.

https://ecommons.luc.edu/social_justice/1

This Article is brought to you for free and open access by the Centers at Loyola eCommons. It has been accepted for inclusion in Social Justice by an authorized administrator of Loyola eCommons. For more information, please contactecommons@luc.edu. 
Human Organization, Vol. 70, No. 4, 2011

Copyright (C) 2011 by the Society for Applied Anthropology

0018-7259/11/040366-10\$.50/1

\title{
Is Immigration Policy Labor Policy?: Immigration Enforcement, Undocumented Workers, and the State
}

\author{
Ruth Gomberg-Munoz and Laura Nussbaum-Barberena
}

\begin{abstract}
Enforcement-oriented immigration programs have spread rapidly from the United States-Mexico border throughout the United States interior in recent years, intensifying the vulnerabilities of undocumented workers. In this article, we draw on our ethnographic research with undocumented workers and activists in the Chicago area to examine the expanded use of instruments such as E-Verify, No-Match letters, and federal-local enforcement collaborations. We consider how accelerated enforcement-oriented immigration policies affect the labor relations of undocumented workers in the Chicago area, and we also explore how immigrant labor leaders help workers ward off the short-term effects of punitive immigration policies as they organize for long-term immigration reform.
\end{abstract}

Key words: immigration enforcement, undocumented immigrants, activism, neoliberalism, transmigration

\section{Introduction}

I $\mathrm{n}$ the United States, enforcement-oriented immigration policies have been concentrated along the United States-Mexico border, while workplace enforcement in the U.S. interior declined drastically during the 1990s and early 2000s (Gorman 2005; Porter 2006; see also Preston 2006). Border-oriented immigration policy has enabled undocumented workers to labor in the U.S. interior with little fear of detection, as it has allowed companies to employ undocumented workers with near impunity (Delgado 1993). This arrangement has led scholars such as Heyman (1998) to caution against overemphasizing the role of the state in directly structuring workplace relationships of immigrants in the United States interior.

While the bulk of immigration enforcement continues to be concentrated on the southern border of the United

Ruth Gomberg-Munoz is Assistant Professor in the Department of Anthropology at Loyola University Chicago. Laura Nussbaum-Barberena is a Ph.D. candidate in the Department of Anthropology at the University of Illinois, Chicago (UIC). The authors are very grateful to all of the workers and activists who participated in this research project. They would also like to thank Molly Doane, Josiah Heyman, Paul Gomberg, Nilda Flores-Gonzalez, and Andy Clarno for their helpful feedback. Nussbaum-Barberena's data were gathered as part of the Chicago Area Study, and her fieldwork was supported by the National Science Foundation under Grant No. 0921414, the UIC Institute for Policy and Civic Engagement, UIC Institute for Research on Race and Public Policy, UIC Great Cities Institute, and UIC Office of Social Science Research.
States, enforcement-oriented immigration programs have spread rapidly throughout the U.S. interior over the last four years. These changes beg a reconsideration of the degree of influence that the state wields over the working conditions of undocumented immigrants. In this article, we draw on our ethnographic research with undocumented workers and activists in Chicago to revisit the presence of the state in immigrant workplaces and communities in light of the recent amplification of several immigration-related policies.

We argue that programs such as No-Match letters and expanded federal-local collaborations increase state presence at immigrant job sites and in immigrant communities, suppressing the ability of undocumented people to negotiate their working conditions. We further argue that one immigration enforcement program, E-Verify, can represent direct state intervention in immigrant workplaces. Recognizing that "cheap labor is not necessarily docile labor," (Delgado 1993:58), we also explore how immigrant labor leaders are responding to these programs by utilizing U.S. labor laws, labor unions, and their own collective resources to help workers ward off the short-term effects of punitive immigration policies as they organize for long-term immigration reform. Ultimately, we hope to shed light on local interactions of state policies, employer control, and worker resistance in the negotiation of working conditions and labor practices among undocumented workers in the Chicago area.

This paper is divided into four parts. First, we briefly review anthropological and historical literature that considers the degree to which immigration policy is a mechanism of state-sponsored labor reproduction. Second, we describe 
immigration policy trends in the current period and discuss instances of labor control by Chicago-area employers wielding policy instruments to discipline immigrant workers. Third, we examine the responses of undocumented immigrants to these measures through their participation in immigrant-led labor groups in Chicago, and we explore the organizing strategies of these groups. In the conclusion, we consider the broader implications of this study for mechanisms of control and resistance in an age of globalization and neoliberal discipline.

The ethnographic data presented in this article are drawn from our fieldwork in Chicago's Mexican immigrant communities and particularly within the immigrant rights movement. Gomberg-Munoz has been both an active ethnographer and organizer in the immigrant rights movement since 2006, and she began collaboration with an immigrant-led workers' center - known here as Latino Chicago Workers' Center (LCWC) - on Chicago's south side in late 2009. NussbaumBarberena's interest in immigrant rights developed during several years spent as an activist/worker in Costa Rica and Nicaragua, where she became involved in the campaign against Central American free trade agreements. Her involvement with Chicago's immigrant rights movement began shortly after her arrival in Chicago in 2008. More recently, Nussbaum-Barberena began collaborating with a suburban Chicago worker's center that we call ADELANTE, as well as a Chicago street vendor's association.

\section{United States Immigration Policies: Direct and Indirect Mechanisms of Labor Control}

The accelerated movement of capital, goods, and people across national borders has generated disagreement within social science scholarship over how to conceptualize the role of the nation-state in defining and regulating transnational migration. Some scholars have suggested that mass migrations may require a reconceptualization of the nation-state that diminishes the role of territoriality as an essential component of nation-state power (Basch, Schiller, and Blanc 1994; Gupta and Aradhana 2006; Malkki 1992). Relatedly, mass unauthorized migration has been perceived as an indication of weakening nation-state hegemony. Thus, Kearney (1998:124-126) has argued, "Everyday thousands of 'undocumented' persons successfully defy the state's power to control their movement into and through [border] space and in doing so contest not only space but also control of their identity." According to this perspective, unauthorized migration occurs in opposition to state control and has the potential to undermine state authority.

Conversely, other scholars have suggested that largescale unauthorized migration is not representative of nationstate weakness, but is rather a manifestation of its power. According to this perspective, national boundaries and state policies funnel and regulate global flows of capital, communications, and labor, perpetuating the inequalities that cause people to migrate in the first place and structuring both the objective and subjective realities of transmigrant workers
(Alvarez 2005; Chang 2000; Cordero-Guzman, Smith, and Grosfoguel 2001; Drainville 1999). As immigration policies ascribe illegal status to segments of the global labor force, they sustain categorical inequalities in a "post racial" era and suppress the costs of transnational and domestic labor alike (De Genova 2005; Gomberg-Munoz 2011; Heyman 2001; Sassen-Koob 1981). Immigration categories and nationbuilding campaigns are thus mechanisms for reproducing vulnerability and powerlessness among a global low-wage work force.

While there is general agreement that punitive immigration policies have negative effects on the wages and working conditions of unauthorized transmigrant workers, there is less agreement about the degree to which federal immigration policies play a direct role in structuring the labor relations of immigrants in the workplace. Heyman (1998) and Delgado (1993) have pointed out that the concentration of immigration enforcement activities on the border, far away from most immigrant workplaces, makes the neoliberal state only an indirect contributor to the super-exploitation of undocumented workers. ${ }^{1}$ Thus, in a 1998 article, Heyman argues that immigration enforcement contributes to super-exploitation of immigrant workers, not through direct repression, but indirectly through stigmatization and transmigrant workers' involvement in conspiracies to avoid detection by law enforcement agents. According to this perspective, ascribing immigration policy a direct role in the super-exploitation of immigrant workers amounts to an overly functionalist view of the capitalist state as a monolithic agent that knows what it wants and knows how to get it. Heyman further argues that a view of the state as a direct agent of labor repression glosses over complex, contentious, and multifaceted processes of power and ignores the agency of working people in directing and transforming the conditions under which they labor.

In the absence of empirical data regarding whether or not (or the degree to which) the crafters of immigration policy take into account labor market impacts of immigration legislation, we do not here resolve the question of whether a functionalist perspective of "immigration policy as labor control" is warranted. However, we wish to make the case that historical and ethnographic data suggest at least three things. First, lawmakers are under pressure from business constituents to maintain supplies of low-wage immigrant labor. Second, lawmakers are also under pressure to tighten the labor market and help create job opportunities for United States citizens, particularly in times of economic crisis. Finally, given these opposing pressures, state policies on immigration that fail to satisfy labor market demands and boost the political capital of lawmakers are adjusted until they do so. This produces immigration policies that appear self-contradictory and ineffectual but that are actually quite effective at maintaining a large and vulnerable undocumented work force.

In the current period, the spread (and even the threat) of interior immigration enforcement has expanded the power of employers over undocumented employees, directly and 
indirectly facilitating the super-exploitation of undocumented immigrant workers. Simultaneously, enforcement-oriented measures give the impression that lawmakers have taken a tough stance on undocumented immigration, but they do not seriously compromise most employers' access to undocumented labor. Ultimately then, enforcement-oriented immigration policies in the United States allow lawmakers to cultivate political capital while they uphold the interests of capitalist enterprises.

\section{Immigration Policy and Labor Control in Historical Perspective}

A historical perspective suggests that United States immigration policies have long been effective at controlling and expanding foreign labor reserves. After immigration policies of the late 19th and early 20th centuries cut off labor supplies from Asia and curbed the immigration of low-wage European workers, the seasonal migration of workers from Mexico was encouraged, and Mexican workers were prized as a source of cheap, temporary agricultural labor (Calavita 1994; Gutierrez 1995). The reliance of U.S. growers on workers from Mexico was accelerated by World War II, when the working male population of the United States was reduced at the same time that demand for productive output of war materials increased. To help fill labor shortages, Mexican workers were imported en masse to the U.S. Southwest, where they harvested the food that would sustain industrial workers in the North and the families of soldiers abroad. To ensure an unhindered labor supply, the United States and Mexico signed a binational treaty in 1942 that came to be known as the Bracero Program. The Bracero Program was a contract worker program that brought nearly five million workers from Mexico to labor in the agricultural fields, construction sites, and factories across the Southwest United States and in cities such as Chicago (Ngai 2004). Much of this labor was undocumented - it is estimated that for every bracero, as many as four workers entered outside of the auspices of the program (De Genova and Ramos-Zayas 2003). In order to suppress the costs of bracero labor and thereby keep down the prices of agricultural products, the Bracero Program included numerous provisions that undermined the collective bargaining power of agricultural workers. Among other things, Bracero workers were contracted to specific employers at specified wages that were lower than the rates that farm workers received elsewhere in the United States (Ngai 2004).

The Bracero Program ended in 1964, and in 1965 immigration from Mexico and other Latin American countries became subject to numerical restriction for the first time ever. Over the next 15 years, the number of visas available to Mexican workers was reduced from an unlimited number to just 20,000 per year (Calavita 1994; Massey, Durand, and Malone 2002). In spite of these new restrictions, the demand for immigrant labor from Mexico has persisted, and Mexican workers have continued to shore up the United States econ- omy with their low-paid labor. In fact, restrictions imposed by the 1965 Act did not stop, or even slow, the movement of workers from Mexico and other areas of Latin America to the United States. Rather, from the 1970s to the present, economic insecurities wrought by neoliberalism combined with increasingly restrictive immigration legislation and persistent demand for immigrant labor in the United States have helped convert a century old labor migration into a "flood" of "illegal" immigrants. ${ }^{2}$

The turn toward restrictive and enforcement-oriented immigration policies has accelerated in the last four decades. The Immigration Reform and Control Act (IRCA) of 1986 made the employment of undocumented immigrants illegal for the first time, and while IRCA multiplied the vulnerabilities of undocumented workers, provisions in the law largely protected employers from prosecution (Calavita 1994; Massey, Durand, and Malone 2002). A decade later, the Illegal Immigration Reform and Immigrant Responsibility Act (IIRAIRA) of 1996 instituted several restrictionist provisions, including 3-year, 10-year, and permanent bars for unauthorized immigrants and cuts in public services for unauthorized and legal immigrants alike. Throughout the 1990s, a series of "operations" on the border, of which 1994's Operation Gatekeeper is the most notorious, made unauthorized border crossings more deadly as they simultaneously boosted a popular public image of the "illegal Mexican immigrant" (Chacon and Davis 2006; De Genova 2005; Massey, Durand, and Malone 2002).

The attacks on the World Trade Center and the Pentagon on September 11, 2001 and the current economic crisis have pushed immigration rhetoric further to the Right, and U.S. immigration policies have taken a decided enforcement-oriented turn in the last decade. In 2003, immigration enforcement came under the auspices of the Department of Homeland Security (DHS) and its Immigration and Customs Enforcement (ICE) division, signaling a broader shift toward the association of unauthorized migration with terrorism and the criminalization of undocumented immigrants. Since then, immigration enforcement has become more aggressive and has expanded at both national and local levels, with interior enforcement roughly quadrupling from 2005 to 2010 (Heyman 2010).

While there is broad recognition that undocumented migration is primarily a labor migration, and that most undocumented people come to the United States in order to work, widespread employment of undocumented workers continues to be tacitly, if not overtly, permitted across the United States. More undocumented males are in the labor force than their citizen or legal permanent counterparts - an estimated 94 percent, compared with 82 percent of U.S.-born men (see Passel and Cohn 2009). While workplace immigration enforcement has increased under the Obama administration, it continues to constitute a very small proportion of immigration enforcement measures. ${ }^{3}$

In addition, as legislators are under pressure simultaneously to maintain reserves of low-wage labor and to create 
employment opportunities for United States citizens, immigration policies appear ever more paradoxical. On the one hand, there has been an acceleration of enforcement at the border and increased cooperation between local and federal agencies; on the other hand, employers are still largely absolved from punishment for employing undocumented workers, and they have a great deal of flexibility in deciding whether or not to apply immigration programs at their companies. This apparent contradiction is consistent with long-standing United States immigration policies that are continually adjusted to uphold the political and economic interests of the state (see Sassen-Koob 1981).

In the following section, we examine three programs that have been recently implemented or expanded in the United States and that, intentionally or not, satisfy labor market demands of employers while giving the appearance of enhanced immigration enforcement. These programs augment employers' power over immigrant workers by increasing their access to information that can be used to discipline or regulate undocumented workers, but they do not, in most cases, cut off employers' access to an undocumented work force.

\section{The Current Situation}

Here we examine three programs, (1) No-Match letters, (2) local-federal collaborations such as $287(\mathrm{~g})$ and "Secure Communities," and (3) E-Verify. The latter two programs were implemented in the last decade and have recently expanded; all have had significant implications for undocumented workers in metropolitan Chicago and throughout the United States. We argue that these programs represent different types of state intervention in the labor relations of immigrant workers, ranging from labor control by proxy to direct labor repression by the state.

\section{No-Match Letters: Immigration Policy and Labor Control by Proxy}

The Social Security Administration (SSA) began issuing "No-Match" letters, officially known as "Employer Correction Requests," in 1994; after a two year respite, the SSA resumed the program in April of 2011. No-Match letters do not formally constitute immigration policy. Rather, according to the SSA website and the letters themselves, the ostensible purpose of No-Match letters is to help the SSA maintain corrected records and to ensure that workers' earnings are credited toward their social security earnings record. The letters are sent to employers who reported more than 10 mismatched W-2s - in which a worker's social security number does not match his or her name - in a given year, and they ask employers to take "reasonable steps" to correct their records. No-Match letters also emphasize that mismatched numbers may be due to a number of factors and do not necessarily indicate that an employee lacks authorization to work in the United States. Further, the SSA (2010) notes that it has no enforcement authority and "cannot share information about mismatched name/SSN combinations on Forms W-2 with other Federal agencies." In fact, using No-Match letters to terminate a worker's employment on suspicion of unauthorized status could constitute a violation of labor laws. For example, in accordance with federal law established by IRCA, employers only have within three days of an employee's hire date to verify work eligibility documents. Reverifying a worker's documents after this three-day period- even as a response to having received a No-Match letter- is not only outside of the scope of federal law, but constitutes a legal violation of workers' privacy.

Nevertheless, we identify No-Match letters as immigration policy by proxy due to their use in disciplining and firing undocumented workers. Our study participants report pervasive worries about No-Match letters, and the use of No-Match letters to threaten and/or terminate the employment of undocumented immigrants in the poultry processing industry has been recently described by Stuesse (2010). We talked with Ricardo, ${ }^{4}$ an undocumented worker who worked in a south side Chicago meatpacking plant for 13 years. In 2008, the plant began moving some of its operations to its Iowa facility, where, according to plant management, wages and taxes are lower. In 2009, the company started to close its lines at the Chicago plant, and in early 2010, management began calling immigrant employees into the office two at a time. The workers were shown No-Match letters and told that they had five days to fix their papers or be fired. Ricardo and his coworkers went to their union, a powerful Chicago local, but were turned away. Ultimately, over a dozen workers, including Ricardo, were terminated, and they have so far been unable to recover their jobs.

No-Match letters put power over undocumented workers directly in the hands of employers. The ambiguity of NoMatch letters allows employers flexibility in how and whether they choose to act on them. Since the SSA has no enforcement authority and cannot share its information with immigration agencies, employers may simply ignore the letters with little fear of repercussions. On the other hand, should it become desirable to terminate or threaten their undocumented workforce, employers can effectively wield the No-Match letters for that purpose. This is what happened in Ricardo's case, in which management at the plant had been receiving the NoMatch letters for the same employees for several years but only used the letters when they wanted to cut their Chicago workforce. Thus, we believe that No-Match letters constitute labor policy by proxy and are a means of indirect oppression of immigrant labor by the state.

\section{Local Community Policing: Indirect Labor Control}

Perhaps the most popular criticism of United States immigration policy concerns the limitation of immigration enforcement powers to federal immigration authorities. Throughout the United States, local and state governments have begun implementing measures that allow their police 
agencies to partner with federal authorities in the enforcement of immigration laws. The most well-known example of this is Arizona's SB 1070, which went into effect on July 29, 2010. The original provisions of SB 1070 would have required police throughout Arizona to investigate the immigration status of anyone they "reasonably suspect" may be undocumented and would have converted unauthorized presence in Arizona from an administrative violation to a criminal one. Throughout the United States, laws which enable local/federal collaboration on immigration enforcement have been implemented by local governments and most often come in one of two forms: 287(g) or "Secure Communities."

In an explicit conflation of unauthorized migration with "terrorism and criminal activity" (ICE 2010a), 287(g) empowers state, county, and local law enforcement agencies to petition for training by ICE in a partnership initiative that subsequently enables local police to enforce immigration law. As of November 2010, over 1,130 state and local officers had been certified through the program since its implementation in January 2000, and these officers are credited with the identification of over 160,000 "potentially removable aliens" at local jails. "Secure Communities" is another popular collaboration between ICE and local, state, and county systems. Through this program, funded by DHS since 2008, a memorandum of agreement allows fingerprints of those booked in the criminal system to be run through FBI and DHS records, recalling any history of past crimes and, if the accused has a record with DHS, his or her immigration status as well. ICE is automatically notified if the fingerprints have a "hit," even if the individual has not been convicted of any crime (National Immigration Forum 2010). These collaborations between ICE and local police forces extend the immigration enforcement arm of the federal government far beyond the nation's borders and into the heart of the United States.

Because of Chicago's long history as a city of immigrants, and because of the heavy reliance on immigrant labor in the city's manufacturing and service sectors, Chicago is widely considered a safe haven for undocumented immigrants. Chicago has even adopted "Sanctuary City" status, which prevents city police from enquiring about a person's immigration status and from sharing information about a person's status with other agencies. However, recent events in Chicago raise doubts about the security of urban undocumented residents. In 2007, ICE conducted a raid against a false documents ring in the heart of Chicago's Latino community, raising fears among Chicago immigrants and inspiring a string of protests. More recently, ICE has conducted several operations that target suspected undocumented gang members in the city (ICE 2010b).

Even so, the vulnerability of Chicago's urban immigrant community pales in comparison to that of its suburban counterpart, which has been subject to a string of anti-immigrant legislation in localities with high concentrations of Latino/a immigrants. In addition to widespread reports of suburban police "turning over" residents' information to ICE (including in Gomberg-Munoz's own suburban community of Blue
Island), in 2010, six Illinois counties - Lake, Madison, McHenry, St. Clair, Will, and Winnebago- entered into the Secure Communities program with the Department of Homeland Security. In suburban communities with large Latino/a populations, such as Carpentersville and Waukegan, highly publicized and emotionally charged debates over 287(g) and "English Only" laws have contributed to a climate of hostility and stigmatization that heightens the vulnerability of undocumented immigrants in Northeast Illinois.

While undocumented workers are far from secure or empowered even in the best of times, Chicago immigrants tell us that they acutely feel the impact of accelerated local enforcement measures. One suburban resident told us that after her suburban community petitioned for 287(g):

[It] became a desert... because you know that at any moment immigration can arrive.... It's a form of terrorism for me. It's a form of terrorism that we're living with day-to-day.

Our research suggests that accelerated enforcement not only intensifies immigrants' fears of arrest and deportation, but also affects their ability to negotiate their working conditions. For example, many suburban residents said that their decisions regarding work are circumscribed by the risks of driving to get to and from work. One of them told us:

The insecurity is because you don't have a driver's license.
If you are driving without a license, you are the one the
police are looking for. Because if you are driving without
a license, it's easier to deport you.

In the absence of reliable public transportation in Chicago's suburbs, some undocumented workers told us that they will tolerate poor working conditions rather than take the risk of a longer commute to a better job. Luisa, a suburban community organizer, explained how the need to drive to get to and from work exacerbates the vulnerability of undocumented workers:

Okay, they caught you driving with no license. Well, how can you get your license if you're undocumented? [They say] you have to have your insurance. Well how can you have your insurance if you're undocumented? How can you drive around? [This is what] drives them to do things, illegal things, such as using somebody else's Social Security [number].... They want to do it right, it's just, how can they do it? You give them tickets, and you put them in jail. They pay everything, and then they go out again, and they're gonna drive again because they need to go to work.

Local immigration enforcement measures have multiple impacts on greater Chicago's undocumented community. In addition to intensifying an overarching climate of fear and anxiety, local-federal collaborations make undocumented people reluctant to move about in their communities and increase their sense of powerlessness. Any of a number of suspected or actual infractions, such as driving without a license, become potential deportation cases. The relative security 
of undocumented people is thus ever more dependent upon the whim of local law enforcement officers. Local-federal immigration enforcement collaborations constitute indirect labor control as they tie undocumented workers more firmly to local employers and constrain workers' ability to seek better jobs and living conditions.

\section{E-Verify: Immigration Policy as Direct Labor Control}

E-Verify is an online program that employers can use to determine the employment eligibility of new hires by verifying information provided on Employment Eligibility Verification forms (or I-9 forms) with the SSA and United States Citizenship and Immigration Services (USCIS). E-Verify was enacted under IIRAIRA in 1996, though web-based accessibility was only implemented in 2004. In September 2009 , federal agencies began requiring contractors to utilize E-Verify for employees on all new federal contracts, and the USCIS website boasts ever-increasing employer participation in the program (USCIS 2010). While E-Verify has only recently been made widely available, it is already having predictable and pernicious effects on Chicago's undocumented labor force. In particular, our research suggests that E-Verify facilitates employers' abilities to discipline their undocumented workers and undermine organizing efforts at immigrant job sites.

We met several employees of one suburban Chicago hotel who said that in December of 2009, the hotel management staff gathered the mostly Latino service staff together for a meeting. A manager asked the workers, "How many of you are in the union?" More than 50 workers raised their hands. "You're all fired," he told them. The dismissals were effective immediately. The workers filed a grievance with their union and enlisted the help of LCWC, a labor rights organization in Chicago. After a protracted struggle lasting several months, the workers won their petition with the National Labor Relations Board. However, being rehired subjected the workers to having their documents checked through E-Verify, and as of now, only the workers with legal status have been able to regain their jobs. In spite of this hollow victory, it is important to note that hotel management was ultimately unsuccessful in busting the union at this location.

One organizer of a union local in Chicago told us that she is aware of several employers who wield the threat of immigration enforcement to undermine union efforts. She described a campaign that she has been involved with, in which one of the most vocal union supporters at a Chicago shop was recently asked for her green card by management, even though she had been employed there for several years. Shortly after, management began asking all of the open union supporters for their work eligibility documents. One manager even reportedly told the workers, "Only people with papers get unions, you won't get a union." Management also spread rumors that ICE was going to conduct a raid at the store as a result of the workers' organizing efforts.
The director of the LCWC told us that E-Verify increases the power of employers. He said:

The employers have all of the power. If they want to apply E-Verify, they can apply it however they want. They can use it to fire the workers who have been there for 10 years, 15 years. And they don't do it because they're patriotic, they do it...so they can hire workers at a lower pay scale.

Unlike with No-Match letters, the federal government sometimes requires certain companies to use E-Verify, giving the state a greater role in controlling immigrant labor. On January 29, 2010, over 200 unionized United Parcel Service (UPS) workers at Chicago's downtown facility received termination notices. The managers at UPS told the workers that because the company has government contracts, it was obligated to verify employees' work eligibility documents using E-Verify. Overnight, hundreds of immigrant workers at UPS lost their jobs; some of these workers had been at the company for 10 years or more. One leader who helped organize the workers told us that, in the case of UPS, the government mandate to use E-Verify overrode the three-day verification period established under IRCA; also, E-Verify was used to check all workers at the plant, even those who do not come into contact with federal packages. Thus, labor leaders charged that the firings violated workers' privacy and were a misapplication of the federal mandate. The workers organized picket lines, generated community pressure on UPS, and even engaged in a hunger strike, but ultimately the workers' campaign to regain their jobs was unsuccessful.

E-Verify, which is established, regulated, and occasionally mandated by the federal government, can constitute a direct mechanism of state control over immigrant labor. In this sense, E-Verify represents a departure from immigration policies that give employers heightened control over their immigrant workforce but do not directly intervene in the labor relations of undocumented workers and their employers. This departure may reflect a serious commitment by the Obama administration to tighten the labor market and open up job opportunities for low skill United States citizens. On the other hand, this may be a cynical attempt to create political capital by giving the appearance that immigration enforcement is taken seriously, without any permanent requirement that employers abide by immigration laws. One activist who helped organize the UPS protest explained that he believes that politicians use instruments like E-Verify to scare American voters. He said:

The United States is in an economic crisis, and immigrants can be blamed for the lack of jobs. Americans ask, how is it possible that people without rights to work have these jobs, our jobs? This is the justification for E-Verify. And the businesses are taking advantage.

E-Verify makes federal immigration data accessible to any employer, anywhere, at any time, greatly expanding the potential for employers to cooperate with federal immigration legislation. Our data suggest that the threat of E-Verify 
is most frequently wielded by employers looking to regulate or discipline an immigrant labor force and thus most often represents an indirect means of state labor control. However, in some instances, such as the UPS example described above, E-Verify is mandated by the government and represents direct intervention by the state in immigrant workplaces.

\section{"Without Legalization There Can Be No Equal Labor Rights": Immigrant Workers Organize in Metropolitan Chicago}

In spite of their heightened vulnerabilities, undocumented workers in Chicago and around the United States are often at the forefront of political struggles (see Delgado 1993; Stuesse 2010; Zlolniski 2003, 2006). Ethnographic examination of the activism of undocumented immigrants is an important complement to our analysis of heightened repression, as it demonstrates how workers utilize their agency, even under seriously constrained conditions, to struggle for rights. An attention to organizing activities of undocumented immigrants also contributes to examinations of "the state from below" (see Delgado 1993; Heyman 1998; Zlolniski 2003) by exploring how undocumented immigrants in the United States help shape class-based resistance, policy discourse, and even immigration legislation itself. In this final ethnographic section, we draw on our fieldwork with two area labor rights centers to explore how immigrant activists in the Chicago area are responding to the recent rise in immigration enforcement measures.

Our fieldwork indicates that accelerated immigration enforcement has had a dual effect on the organizing strategies of immigrant workers and activists in the Chicago area. On the one hand, a heightened climate of fear has disheartened some immigrant residents of metropolitan Chicago, causing them to retreat inside of their homes or pushing them out of the area altogether. A suburban immigrant rights activist said that pervasive fear has dampened his organizing efforts:

I've been trying to motivate people to join the campaign. Because many people lose energy or they lose motivation, not having documents and not having work.... They say, I can't take any more.... Many in the community become disillusioned.

But other organizers say that immigration enforcement has galvanized the immigrant community and given new life to the immigrant rights movement. One undocumented organizer who helped lead the unsuccessful fight against the adoption of $287(\mathrm{~g})$ in her community told us that the debate over local immigration policy has politicized her suburban town. She explained:

Today [this community] is not the same as it was. [It] is a community with its eyes open, it's a community where, if you talk about $287(\mathrm{~g})$, the people will tell you about it backward and foreword.
Furthermore, as more undocumented workers are affected by programs such as No-Match letters and E-Verify, more workers look for recourse at labor rights and immigrant rights centers. At these centers, they encounter an active community of organizers and, inevitably, some of the workers become involved in labor rights and/or immigrant rights movements.

Both of the centers where we focused our fieldwork are led by veteran organizers, but the centers themselves were created recently, in 2009. One of these centers, which we call LCWC, is located in Chicago's Little Village neighborhood. Little Village, along with its neighbor to the east, Pilsen, is the geographic and symbolic heart of greater Chicago's Mexican community. The other center, which we call ADELANTE, is located in a northern Chicago suburb with a high proportion of Latino and immigrant residents that was at the center of heated struggle over a 2006 city council resolution to adopt $287(\mathrm{~g}) .^{5}$ These centers have a relationship with each other, as LCWC staff helped train staff at ADELANTE; this may partially explain similarities in their approaches to labor rights organizing. Both centers are led and staffed by immigrants - most of whom are from Mexico and some of whom are undocumented - who rigorously defend their autonomy from more powerful organizations in the area.

Immigrant rights discourses at these centers highlight contradictions in a system that allows widespread consumption of undocumented labor but denies rights to undocumented workers. As workers and activists organize around immigrant rights issues, they discursively reposition themselves from a socially marginal group to a productive force that provides labor central to economic growth. In fact, in immigrant rights discourse, undocumented immigrants frequently emphasize that they are hard working, tax paying, law abiding, and in general good U.S. citizens - even though they are excluded from United States citizenship. In this way, they make a moral claim for citizenship rights and distance themselves from claims that they are dangerous usurpers. Some of our respondents go further, asserting that immigration restrictionists, not unauthorized immigrants, violate the historical principles of good United States citizenship. When asked whether undocumented migration was a crime, one worker responded:

\footnotetext{
Yes, you're violating the border, but this country was founded by immigrants. Their descendants are the same ones putting up barriers now that they're already here. I don't think that's right.... Those people don't have the right to change the laws to keep other people out.
}

By positioning themselves as rightful heirs to a historical legacy of inclusion, these workers tap into hegemonic narratives of "America as a nation of immigrants" and strengthen their claims to belonging and rights.

This strategy of pointing out inconsistencies in the immigration system is not just discursive, but practical, as immigrant rights activists use labor laws to challenge immigration policies. For example, according to provisions of 1986's IRCA, employers only have within three days of an employee's hire date to 
verify work eligibility documents. Reverifying a worker's documents after this three-day period is not only outside of the scope of IRCA, but actually constitutes a violation of workers' privacy. Staff members at LCWC often use these grounds to file cases with the National Labor Relations Board against employers who fire workers as a result of No-Match letters. While workers typically do not regain their jobs, employers may be forced to pay fired workers a $\$ 500$ fine. Yet mandates to use E-Verify - as we saw in the UPS case - can require an employer to verify an employee's work eligibility at any time. In effect, E-Verify can be used to violate provisions of IRCA, an inconsistency that immigrant rights activists have tried to turn to their advantage. "What we're saying," one labor rights activist who helped organize the UPS workers told us, "is that they can't use a new law to break a preexisting law. That doesn't make any sense."

Immigrant leaders also find creative ways to participate in the political process, even when constrained by undocumented status. For example, when one suburban city council voted to adopt $287(\mathrm{~g})$ after an intense, protracted struggle, local immigrant rights leaders began moving away from their alliances with more powerful Chicago organizations and turned instead to the local Latino/a immigrant community. They organized a community campaign against the incumbent mayor and vocally supported a mayoral candidate who was more sympathetic to immigrant rights. Local undocumented leaders encouraged the candidate to speak openly to the Latino/a community about his opposition to $287(\mathrm{~g})$, and while their immigration status prevented them from formal participation in the electoral process, undocumented leaders take credit for helping the challenger win the election. One organizer told us:

We closed the office and went on the campaign trail.... You should ask [local political leadership] who got [the mayor] elected. You should go ask the mayor who got him elected.... We got him elected.

Perhaps most importantly, leaders at LCWC and ADELANTE explicitly link labor rights with immigrant rights, arguing that laboring conditions for citizen workers will only be improved with the full inclusion of immigrant workers into the polity. This class analysis was most consistently articulated by veteran activists who tended to have a more developed political perspective on neoliberalism, migration, and workers' rights. For example, veteran organizer José told us:

[Immigrant rights] is a matter of justice, first and foremost, but it is also a matter of strengthening the working class to be in a better position to fight for unions, to fight for better wages.... It's important to have a broader social analysis.

A union organizer and activist in the immigrant rights movement said:

I don't believe in borders.... The open, free market system has to allow movement of labor, if you don't you're just creating inequality by trapping people in these categories.
The association of workers' rights and immigrant rights reflects veteran activists' engagement with broader issues of globalization and international labor migration.

\section{Conclusion}

Over the past four decades, United States economic policies have aggressively pursued the globalization of all aspects of production except for labor, further undermining subsistence practices in regions such as Mexico and mobilizing a massive transmigrant labor force. Paradoxically, United States immigration policies have become increasingly restrictive and punitive, subjecting transmigrant workers to draconian control in their places of work and residence. In keeping with a long history of U.S. immigration policy that has been geared toward empowering employers of transmigrant workers and disempowering workers themselves, contemporary policies do not reduce the undocumented labor force in the United States so much as heighten its vulnerability. Our data do not, we contend, warrant a reconceptualization of this framework. Indeed, for the most part current policies patently do not prevent undocumented people from working or employers from employing them.

Without claiming to resolve the question of whether state agents, via immigration policies, intend to produce an extra vulnerable immigrant labor force in the United States, our analysis suggests that they do so, and effectively. This interpretation challenges the notion that widespread employment of unauthorized workers subverts the power of the U.S. nationstate. Instead, our analysis suggests that parallel processes of capitalist penetration of the "periphery," restrictive immigration policies, and tacit tolerance of unauthorized employment uphold nation-state power by at once reproducing conditions favorable to capitalist industries and giving the appearance that national policies confer special rights and privileges on citizens.

However, the pernicious effects of accelerated immigration enforcement in the United States interior should not be underemphasized. As the vulnerabilities of undocumented immigrants are compounded, they are ever more subject to super-exploitation. This suppresses the ability of all United States workers - documented and undocumented, immigrant and native born - to organize effectively and undermines their collective bargaining power. ${ }^{6}$

In spite of the harmful effects of accelerated immigration enforcement on undocumented workers, the amplification of punitive immigration policies does not necessarily represent a fundamental transition from indirect to direct state intervention in immigrant workplaces. While E-Verify and workplace raids do allow the state to directly intervene in the labor relations of undocumented workers, the balance of decision making power in whether to apply immigration policies continues to rest in the hands of employers. We see little indication that contemporary policies represent a prolonged shift toward mass deportations and workplace enforcement, though this may change as the crisis of capitalist 
overproduction deepens. It is not inconceivable (though we think it unlikely) that in the near future there will be a sincere attempt to nationalize the U.S. labor market by closing off jobs to non-United States workers.

However, our data do suggest that periods of economic crisis such as the current one highlight contradictions inherent in this system. On the one hand, widespread economic insecurities deepen anti-immigrant sentiment, and many United States citizens question why governmental policies are so apparently ineffective at enforcing immigration laws. On the other hand, undocumented workers and activists point to the apparent hypocrisy of policies that allow for widespread consumption of their labor and tax dollars while denying them access to rights. Further, they argue that restrictive immigration policies are inconsistent with America's identity as a nation of immigrants.

On a broader level, immigrant rights discourse in the Chicago area suggests important things about the contemporary political climate of the United States. Insofar as undocumented workers consider the borders that they cross and the laws that regulate them to be legitimate, they do not challenge the authority of the nation-state to ascribe illegal status to foreign-born workers. This has the side effect of limiting mainstream discourse about immigrant rights to nationalist appeals ("We deserve legalization because we are good, taxpaying Americans, too.") or creating contradictions for workers who question the legitimacy of their unauthorized status. Further, the acceptance of borders and immigration categories absolves developed nations like the United States from responsibility for having helped create the global flows that generate and sustain unauthorized migration in the first place, further reinforcing nationalist hegemonies.

\section{Notes}

${ }^{1}$ Following Heyman (1998:158), we believe that undocumented workers are super-exploited; that is, that they work "faster and harder for the same pay (and less frequently, for lower pay), and struggle to avoid or limit workplace authority less often" than other workers.

\footnotetext{
${ }^{2}$ Another contributing factor to sustained migration of workers from Latin America - and from Mexico in particular - to the United States are the transnational social networks that workers have been building for more than a century. These networks create self-sustaining and longstanding relationships between workers in Latin America and family and jobs in the United States.
}

${ }^{3}$ The passage of IRCA in 1986 made it illegal to employ undocumented workers, triggering an initial wave of workplace immigration enforcement. However, over the following two decades, workplace enforcement of immigration laws declined dramatically, and the number of worksite arrests dropped from 7,620 in 1993 to only 445 in 2003 (Gorman 2005). Beginning in 2006, ICE accelerated its worksite enforcement program, leading to a surge in worksite immigration raids and arrests. From the 2003 low of 445, workplace arrests jumped to 1,116 in 2005, to 3,667 in 2006, and to 5,184 in 2008, the last year reported on the ICE website (ICE 2010a). In spite of ICE's pledge to target "criminal aliens" and "unscrupulous employers," the vast majority of workplace arrests are "administrative," not criminal, and involve unauthorized workers, not their employers. For example in 2008, only 1,100 criminal arrests were made at workplaces, compared to more than 5,000 administrative arrests (ICE 2010a).

${ }^{4}$ All names of study participants have been changed to protect their anonymity.

${ }^{5}$ Although the city council voted to adopt 287 (g) in 2006, subsequent political changes in the community, including the election of a new mayor, have prevented its implementation. However, this community is located in Will County, one of six Illinois counties to enter DHS's "Secure Communities" program.

${ }^{6}$ Readers may also want to consult Gordon, Edwards, and Reich (1982) for a discussion of how segmentation of the labor force hurts workers as a collective unit.

\section{References Cited}

Alvarez, Robert

2005 Mangos, Chiles, and Truckers: The Business of Transnationalism. Minneapolis: University of Minnesota Press.

Basch, Linda, Nina Glick Schiller, and Cristina Szanton Blanc 1994 Nations Unbound: Transnational Projects, Postcolonial Predicaments, and Deterritorialized Nation-States. Amsterdam, The Netherlands: Gordon and Breach Science Publishers.

Calavita, Kitty

1994 United States Immigration and Policy Responses: The Limits of Legislation. In Controlling Immigration. Wayne Cornelius, Philip Martin, and James Hollifield, eds. Pp. 55-82. Stanford, Calif.: Stanford University Press.

Chacon, Justin, and Mike Davis

2006 No One is Illegal: Fighting Racism and State Violence on the United States-Mexico Border. Chicago, Ill.: Haymarket Books.

Chang, Grace

2000 Disposable Domestics: Immigrant Women Workers in the Global Economy. Cambridge, Mass.: South End Press.

Cordero-Guzman, Hector, Robert C. Smith, and Ramon Grosfoguel, eds. 2001 Migration, Transnationalization, and Race in a Changing New York. Philadelphia, Pa.: Temple University Press.

De Genova, Nicholas

2005 Working the Boundaries: Race, Space, and "Illegality" in Mexican Chicago. Durham, N.C.: Duke University Press.

De Genova, Nicholas, and Ana Y. Ramos-Zayas

2003 Latino Crossings: Mexicans, Puerto Ricans, and the Politics of Race and Citizenship. New York: Routledge.

Delgado, Hector

1993 New Immigrants, Old Unions: Organizing Undocumented Workers in Los Angeles. Philadelphia, Pa.: Temple University Press.

Drainville, Andre C.

1999 The Fetishism of Global Civil Society: Global Governance, Transnational Urbanism, and Sustainable Capitalism in the World Economy. In Transnationalism From Below. Michael Peter Smith and Luis Eduardo Guarnizo, eds. Pp. 35-63. New Brunswick, N.J.: Transaction Publishers.

Gomberg-Munoz, Ruth

2011 Labor and Legality: An Ethnography of a Mexican Immigrant Network. New York: Oxford University Press. 
Gordon, David, Richard Edwards, and Michael Reich

1982. Segmented Work, Divided Workers: Cambridge: Cambridge University Press.

Gorman, Anna

2005 Employers of Illegal Immigrants Face Little Risk of Penalty. Los Angeles Times, May 29. URL $<$ http://articles.latimes. com/2005/may/29/local/me-employers29> (August 29, 2011).

Gupta, Akhil, and Sharma Aradhana

2006 Globalization and Postcolonial States. Current Anthropology 47(2):277-307.

Gutierrez, David G.

1995 Walls and Mirrors: Mexican Americans, Mexican Immigrants, and the Politics of Ethnicity. Berkeley: University of California Press.

Heyman, Josiah

1998 State Effects on Labor Exploitation: The INS and Undocumented Immigrants at the Mexico-United States Border. Critique of Anthropology 18(2):157-180.

2001 Class and Classification at the United States-Mexico Border. Human Organization 60(2):128-140.

2010 Human Rights and Social Justice Briefing 1: Arizona's Immigration Law- S.B. 1070. Oklahoma City: Society for Applied Anthropology.

Immigration and Customs Enforcement (ICE)

2010a Fact Sheet: Delegation of Immigration Authority Section 287(g) Immigration and Nationality Act. URL: $<$ http://www.ice. gov/news/library/factsheets/287g.htm> (November 26, 2010).

2010b 20 Arrested in Chicago Area During ICE Operation Targeting Gang Members. URL: $<$ http://www.ice.gov/news/ releases/1009/100920chicago.htm $>$ (November 26, 2010).

Kearney, Michael

1998 Transnationalism in California and Mexico at the End of Empire. In Border Identities: Nation and State at International Frontiers. Thomas M. Wilson and Hastings Donnan, eds. Pp. 117-141. Cambridge, United Kingdom: Cambridge University Press.

Malkki, Liisa

1992 National Geographic: The Rooting of Peoples and the Territorialization of National Identity Among Scholars and Refugees. Cultural Anthropology 7(1):24-44.

Massey, Douglas, Jorge Durand, and Nolan J. Malone

2002 Beyond Smoke and Mirrors: Mexican Immigration in an Era of Economic Integration. New York: Russell Sage Foundation.

National Immigration Forum

2010 Secure Communities. URL: $<$ http://www.immigrationforum. org/images/uploads/Secure_Communities.pdf $>$ (November 26, 2010).
Ngai, Mae

2004 Impossible Subjects: Illegal Aliens and the Making of Modern America. Princeton, N.J.: Princeton University Press.

Passel, Jeffrey, and D'Vera Cohn

2009 A Portrait of Unauthorized Immigration in the United States. URL:<http://pewhispanic.org/files/reports/107.pdf > (August 13, 2009).

Porter, Eduardo

2006 The Search for Illegal Immigrants Stops at the Workplace. New York Times, March 5 URL:<http://www.nytimes. com/2006/03/05/business/yourmoney/05view.html $>$ (August 29, 2011).

Preston, Julia

2006 Pickers Are Few and Growers Blame Congress. New York Times, September 22 URL: <http://www.nytimes. com/2006/09/22/washington/22growers.html.> (August 29, 2011).

Sassen-Koob, Saskia

1981 Towards a Conceptualization of Immigrant Labor. Social Problems 29(1):65-85.

Social Security Administration (SSA)

2010 Overview of Social Security Employer No-Match Letters Process. URL: $<$ http://www.ssa.gov/legislation/nomatch2.htm> (November 26, 2010).

Stuesse, Angela

2010 What's Justice and Dignity Got to Do With It? Migrant Vulnerability, Corporate Complicity, and the State. Human Organization 69(1):19-30.

United States Citizenship and Immigration Services (USCIS)

2010 What is E-Verify? URL:<http://www.uscis.gov/portal/site/ uscis/menuitem.eb1d4c2a3e5b9ac89243c6a7543f6d1a/?vgnex toid $=\mathrm{e} 94888 \mathrm{e} 60 \mathrm{a} 405110 \mathrm{VgnVCM} 1000004718190 \mathrm{aRCRD} \& \mathrm{v}$ gnextchannel $=\mathrm{e} 94888 \mathrm{e} 60 \mathrm{a} 405110 \mathrm{VgnVCM} 1000004718190 \mathrm{aR}$ CRD $>$ (November 26, 2010).

Zlolniski, Christian

2003 Labor Control and Resistance of Mexican Immigrant Janitors in Silicon Valley. Human Organization 62(1):39-49.

2006 Janitors, Street Vendors, and Activists: The Lives of Mexican Immigrants in Silicon Valley. Berkeley: University of California Press. 